HERRERA, C. M. 1984. A study of avian frugivores, bird-dispersed plants, and their interaction in Mediterranean scrublands. Ecological Monographs 54:1-23.

HERRERA, C. M. 1985. Determinants of plant-animal coevolution: the case of mutualistic dispersal of seeds by vertebrates. Oikos 4:132-141.

HERRERA, C. M. 1986. Vertebrate-dispersal plants: why they don't behave the way they should. Pp. 5-18 in Estrada, A. \& Fleming, T. H. (eds). Frugivores and seed dispersal. Dr W. Junk Publishers, The Hague. $392 \mathrm{pp}$.

HERRERA, C. M. \& JORDANO, P. 1981. Prunus mahaleb and birds: the high-efficiency seed dispersal systems of a temperate fruiting tree. Ecological Monographs 51:203-218.

HOWE, H. F. \& SMALLWOOD, J. 1982. Ecology of seed dispersal. Annual Review of Ecology and Systematics 13:201-228.

HOWE, H. F., SCHUPP, E. W. \& WESTLEY, L. C. 1985. Early consequences of seed dispersal for a neotropical tree (Virola surinamensis). Ecology 66:781-791.

JANZEN, D. H. 1970. Herbivores and the number of tree species in tropical forests. American Naturalist 104:501-528.

JANZEN, D. H. 1983a. Seed and pollen dispersal by animals: convergence in the ecology of contamination and sloppy harvest. Biological Journal of the Linnean Society 20:103-113.

JANZEN, D. H. 1983b. Dispersal of seeds by vertebrate guts. Pp. 232-262 in Futuyama, D. J. \& Slatkin, M. (eds). Coevolution. Sinauer, Sunderland, Mass. 250 pp.

LEVEY, D. J. 1986. Methods of seed processing by birds and seed deposition patterns. Pp. 147-158 in Estrada, A. \& Fleming, T. H. (eds). Frugivores and seed dispersal. Dr W. Junk Publishers, The Hague. 392 pp.

MANASSEE, R. S. \& HOWE, H. F. 1983. Competition for dispersal agents among tropical trees: influences of neighbors. Oecologia (Berl.) 59:185-190.

PENNINGTON, T. D. \& SARUKHAN, J. 1968. Arboles tropicales de Mexico. Instituto Nacional de Investigaciones Forestales. Mexico City, Mexico. 300 pp.

WHEELWRIGHT, N. T. \& ORIANS, G. H. 1982. Seed dispersal by animals: contrasts with pollen dispersal, problems of terminology, and constraints on coevolution. American Naturalist 119:402-413.

Accepted 26 May 1987.

\title{
ANNOUNCEMENT
}

\section{Tropical plant ecology symposium volume}

Supplement 1, Volume 35 of the Revista de Biologia Tropical is the proceedings of an international workshop, 'Ecología y Ecofisiología de Plantas en los Bosques Mesoamericanos', which was held in Costa Rica in 1985. The meeting brought together plant ecologists and ecophysiologists who are working at four Neotropical sites: La Selva Biological Station (Costa Rica), Estación Los Tuxtlas (Mexico), Estación Chamela (Mexico), and Barro Colorado Island (Panama). The meeting focused on current research in tropical plant demography and ecophysiology, population genetics, herbivory, and the interfaces among these areas. The workshop volume, edited by D. Clark, R. Dirzo, and N. Fetcher, is in Spanish, with English abstracts. Included are research papers based on the invited talks, panel reports on the current status and need of the focal research areas, and abstracts of the poster presentations.

Copies may be obtained from: Oficina de Difusión Científica, Vice-Rectoría de Investigación, Universidad de Costa Rica, Ciudad Universitaria, COSTA RICA (US $\$ 12.00$ per copy, sent air mail; $\$ 9.00$, sent surface mail; send payment as cheques or money orders made out to Revista de Biología Tropical). 